PRZEGLĄD NAUK HISTORYCZNYCH 2019, R. XVIII, NR 2

http://dx.doi.org/10.18778/1644-857X.18.02.09

C O P E

JM13714

Justyna Gazuszka

UNIWERSYTET JAGIELLOŃSKI*

(iD https://orcid.org/0000-0002-1714-0179

\title{
Senatorowie wobec spraw wyznaniowych na sejmie 1597 roku
}

Streszczenie. Artykuł omawia stosunek senatorów do spraw wyznaniowych na sejmie w 1597 r. Było to niezwykle burzliwe zgromadzenie, pierwsze po zawarciu unii brzeskiej (1596). Pokazuje duże poruszenie, jakie wywołał ów akt w wielonarodowym społeczeństwie Rzeczypospolitej polsko-litewskiej. Obrona prawosławia podczas obrad sejmu przez protestantów ukazywała również sojusz między dysydentami. W jego dziejach analizowany przeze mnie sejm zajmuje miejsce szczególne, po raz pierwszy bowiem na jego forum doszło do współpracy między prawosławnymi a protestantami w obronie konfederacji warszawskiej zawartej w 1573 r. Nie było to przypadkowe i doraźne łączenie sił w momencie zagrożenia swobód wyznaniowych, ale długofalowa i dobrze przemyślana strategia, obejmująca pełen wachlarz działań.

Słowa kluczowe: senatorowie, sprawy wyznaniowe, sejm, unia brzeska, protestanci, Zygmunt III Waza.

W

swoim krótkim opracowaniu na temat sejmu z 1597 r. ${ }^{1}$ Jan Rzońca poświęcił sprawom wyznaniowym dziesięć stron, sygnalizujac pewne problemy, które pojawiły się podczas dyskusji w trakcie zgromadzenia. Nie analizował dokładniej ani treści poszczególnych wystąpień senatorów w sprawach wyznaniowych, ani też nie przedstawiał ich na szerszym tle, jakim była sytuacja wewnętrzna Rzeczypospolitej u schyłku XVI w. Sejm

* Wydział Historyczny, Instytut Historii, Zakład Historii Polski Nowożytnej, e-mail: justynagaluszka92@gmail.com

1 J. Rzońca, Sejmy z lat 1597 i 1598, cz. 1 (Bezowocny sejm w 1597 roku), Warszawa 1989, s. 78-87. 
ten, w świetle badań Tomasza Kempy² i Leszka Jarmińskiego ${ }^{3}$, zajmuje miejsce szczególne, po raz pierwszy bowiem na jego forum doszło do współpracy między prawosławnymi a protestantami w obronie konfederacji warszawskiej zawartej w 1573 r. W swoich opracowaniach T. Kempa udowadnia, że nie było to przypadkowe i doraźne łączenie sił w momencie zagrożenia swobód wyznaniowych, ale długofalowa i dobrze przemyślana strategia, obejmująca pełen wachlarz działań.

W tekście zostały wykorzystane zarówno źródła rękopiśmienne, jak i drukowane. W 20 tomie Scriptores Rerum Polonicarum Eugeniusz Barwiński zamieścił cztery diariusze sejmowe z 1597 r. ${ }^{4}$ Pierwszy $z$ nich, najobszerniejszy, nieznanego autorstwa, został zadedykowany kasztelanowi krakowskiemu Januszowi Ostrogskiemu ${ }^{5}$. Miał on łożyć na utrzymanie oraz wykształcenie nieznanego $z$ imienia i nazwiska autora. Diariusz był dla niego jedna $z$ pierwszych prób literackich podjętych po powrocie $z$ zagranicy, stąd pewna rozwlekłość narracji, pomijanie często ważnych spraw, kwitowanie debat w izbie poselskiej stwierdzeniami, że sa to „zwykłe rozruchy i hałas". Na korzyść tej relacji przemawia jednak to, że autor podawał przebieg sejmu bezstronnie, nie należał bowiem do żadnego stronnictwa. Drugi diariusz, spisany po łacinie, został zadedykowany wojewodzie poznańskiemu Hieronimowi Gostomskiemu. Nie jest to dokładne przedstawienie obrad sejmowych dzień po dniu, lecz próba podsumowania i szerszego spojrzenia na obrady w 1597 r. Autor wskazuje m.in. podobieństwa i różnice między wotami senatorskimi, informuje o wyznaniu danego posła (co może wyjaśniać zajmowane przez tę osobę stanowisko w danej sprawie). Trzeci diariusz, spisany przez Andrzeja Redera, burmistrza Malborka, przedstawiciela miast Prus Królewskich na sejmie, jest bardzo treściwy, mimo że autor skupiał się na sprawach prowincji pruskiej, ponadto nie doprowadził opisu do końca obrad sejmowych, a jedynie do 10 marca 1597 r. Bardzo ważnym uzu-

${ }^{2}$ T. Kempa, Wobec kontrreformacji. Protestanci $i$ prawosławni $w$ obronie swobód wyznaniowych $w$ Rzeczypospolitej $w$ końcu XVI $i$ w pierwszej połowie XVII wieku, Toruń 2007.

${ }^{3}$ L. Jarmiński, Bez użycia siły. Działalność polityczna protestantów $w$ Rzeczypospolitej u schyłku XVI wieku, Warszawa 1992, s. 174-192.

${ }^{4}$ Dyaryusze sejmowe r. 1597, wyd. E. Barwiński, Scriptores Rerum Polonicarum [dalej: SRP], t. XX, Kraków 1911.

${ }^{5}$ Chodzi o Janusza Konstantynowicza Ostrogskiego (ok. 1554-1620), syna Konstantego Wasyla Ostrogskiego, od 1593 r. kasztelana krakowskiego. 
pełnieniem jest diariusz $z$ dawnego Archiwum Gdańskiego, zatytułowany Recessus oder Vielmehr diaria dessen was publice auf dem allgemeinen Reichstag zu Warschau, so wol in der Rat, wie auch landboten stueben taeglichen gehandelt worden im 1597 Jahre. Barwiński doceniał to ostatnie $z$ przywołanych źródeł zwłaszcza za jego zwięzłość, dokładność, celność podsumowań. Podkreślał jego szczególne znaczenie dla poznania przebiegu obrad w izbie poselskiej, gdyż umieszczone tam opisy wskazuja na obycie polityczne autora relacji. Cennym dodatkiem okazały się zebrane przez Barwińskiego akta sejmikowe. Wśród nich znajdują się m.in. dwie propozycje królewskie na sejmiki, memoriał województw poznańskiego i kaliskiego, poprzedzający zwołanie sejmików i uchwały niektórych sejmików. Wśród źródeł brakowało uchwał województwa sandomierskiego i lubelskiego, które znalazłam w Bibliotece Narodowej w Warszawie. Barwiński sugerował poszukiwanie uchwał sejmikowych w archiwach prywatnych: Zamoyskich, Radziwiłłów, Sapiehów ${ }^{6}$.

W pracy wykorzystano przede wszystkim diariusze przechowywane w: Archiwum Państwowym w Gdańsku, Tajnym Archiwum Państwowym Fundacji Pruskiego Dziedzictwa Kulturowego (Geheimes Staatsarchiv Preußischer Kulturbesitz) w Berlin-Dahlem, Bibliotece Kórnickiej Polskiej Akademii Nauk, Bibliotece Ksiażat Czartoryskich w Krakowie oraz materiały sejmikowe ze zbiorów Archiwum Głównego Akt Dawnych w Warszawie (Archiwum Radziwiłłów, dział II „Dokumenty historyczne”). Pozwoliło to na skonfrontowanie podanych przez badaczy informacji, dostrzeżenie nieścisłości czy błędów, co umożliwiło kompletne (w świetle znanych mi materiałów) zaprezentowanie problematyki religijnej w wystapieniach senatorów podczas obrad sejmu 1597 r. W pracy wykorzystałam również inne dokumenty z działu II Archiwum

${ }^{6}$ Barwiński wskazał Bibliotekę Książąt Czartoryskich, rękopisy: 1620 i 2724 (korespondencja Mikołaja Zebrzydowskiego, oryginały i odpisy aktów publicznych z końca XVI w.). Rękopis 1620 zawiera materiały z lat 1590 i 1591, w rękopisie 2724 przechowywane sa materiały $z$ lat 1592-1598. W księdze od strony 122 do strony 324 znajduja się materiały sejmikowe z 1598 r., a od strony 379 do strony 436 lauda $z 1592$ r., fragmenty diariusza sejmowego $z$ tego roku, akta zjazdu w Lublinie i Jędrzejowie. W źródle odnaleźć można pojedyncze akta sejmikowe i sejmowe $z$ lat 1593-1596. Rękopis 2243 z Biblioteki Książąt Czartoryskich zawiera zbiór materiałów $z$ lat 1587-1598, m.in. lauda i instrukcje przyjęte na sejmiku wileńskim i artykuły średzkie. Nie sa to zatem materiały zmieniające wiedze na temat sejmu w $1597 \mathrm{r}$. 
Radziwiłłów, m.in. wota senatorów $z$ województwa wileńskiego, obecnych na sejmiku poselskim województwa wileńskiego, który poprzedzał sejm warszawski. Uznałam za zasadne skorzystanie $z$ tego źródła $z$ uwagi na znaczenie sejmiku wileńskiego dla Wielkiego Księstwa Litewskiego, województwo litewskie bowiem jako tzw. górne miało duże znaczenie.

W latach siedemdziesiątych XVI w. w życiu politycznym państwa, koncentrującym się w sejmie i na sejmikach, dominowała elita zwiąana $z$ ruchem egzekucyjnym, który w znacznej mierze składał się $z$ niekatolików. Chociaż $z$ czasem odsetek szlachty innowierczej się zmniejszał, to ciągle pozostawała ona liczaca się siła, zwłaszcza w Wielkim Księstwie Litewskim ${ }^{7}$. Szesnaste stulecie kończyło się w Rzeczypospolitej napiętą sytuacja spraw wyznaniowych, do których należały niewyjaśnione kwestie tumultów religijnych, brak obwarowania konfederacji warszawskiej artykułami wykonawczymi czy też rozłam w Cerkwi prawosławnej i pojawienie się nowego wyznania po synodzie odbytym w Brześciu w październiku 1596 r. Pierwsza część panowania Zygmunta III Wazy (do rokoszu Zebrzydowskiego) była arena walki o uchwalenie aktów wykonawczych do konfederacji warszawskiej ${ }^{8}$. Dysydenci oczekiwali zabezpieczenia ich praw w postaci konstytucji sejmowych. Ostatnia $z$ nich pochodziła $z$ roku 1596 i powtarzała sformułowania używane we wcześniejszych tego typu dokumentach $z$ czasów batoriańskich. Postanawiano w niej, że każdy, kto wszczynałby jakieś rozruchy i tumulty: „ma bydź sadzon, karan y hamowan, salva apellatione do Nas na Sejm: które sprawy, w pierwszy tydzień Seymu, między sprawami kryminalnemi sądzić mamy"9. W konstytucji tej pojawił się również zapis o jej czasowym charakterze, do momentu pojawienia się wyników specjalnej komisji królewskiej, która miała zbadać sprawę tumultu krakowskiego z 1591 r., znaleźć odpowiedzialnych za te wystapienia, jak również stworzyć dla całego kraju mechanizmy zapobiegajace podobnym wystapieniom, bąź też artykuły wykonawcze do postanowień konfederacji warszawskiej, które usprawniłyby poszukiwanie prowodyrów wystąpień i zapobiegłyby im w przyszłości.

7 W. Kriegseisen, Stosunki wyznaniowe $w$ relacjach państwo-kościół między reformacja a oświeceniem, Warszawa 2010, s. 534.

8 Por. M. Korolko, Klejnot swobodnego sumienia. Polemiki wokół konfederacji warszawskiej w latach 1573-1658, Warszawa 1973, s. 34-109.

${ }^{9}$ Konstytucja „O tumulciech”, [w:] Volumina legum, wyd. J. Ohryzko, t. II, Petersburg 1859, s. 366. 
Na ziemiach ruskich, należących zarówno do Korony, jak i do Wielkiego Księstwa Litewskiego, przytłaczającą większość stanowili wyznawcy prawosławia. Istniała tam oczywiście zhierarchizowana struktura Kościoła rzymskiego $z$ metropolia halicka na czele, jednakże jeszcze w XVI w. niewielkie skupiska ludności tego wyznania obsługiwane były przez skromna liczbę parafii. Właściwy czasom poprzedzajacym panowanie Zygmunta III brak antagonizmów na tych terenach tłumaczyć można również kryzysem trawiącym obie części Kościoła. Dopiero nowinki religijne $z$ zachodu Europy spowodowały ferment $w$ tychże wyznaniach. Odegrały one znaczaca rolę $\mathrm{w}$ procesie tworzenia unii między Wschodem a Zachodem ${ }^{10}$.

Kwestie te były niewatpliwie skomplikowane i wzbudzały wiele emocji także na sejmikach poprzedzajacych zwołany na luty 1597 r. sejm warszawski ${ }^{11}$. Niekiedy możemy mieć pewne trudności $z$ oddzieleniem problemów innowierczych od pozostałych, często szlachta jedynie ogólnikowo artykułowała swoje obawy o „pokój wewnętrzny”. Zygmunt III wielokrotnie konsultował $z$ senatorami treść listów deliberatoryjnych, które miały zostać rozesłane pod koniec 1596 r. do sejmików przez kancelarię królewską. Z korespondencji między królem, Lwem Sapiehą, Krzysztofem Radziwiłłem „Piorunem” i Mikołajem Krzysztofem Radziwiłłem „Sierotka” możemy się dowiedzieć o planach królewskich wobec planowanego sejmu $^{12}$. Monarcha skupiał się na niebezpieczeństwie zewnętrznym (tureckim i tatarskim), pod dyskusję należało poddać kwestię przystapienia Rzeczypospolitej do ligi antytureckiej, co gorąco popierał papież Klemens VIII i jego wysłannik do polskiego monarchy, kardynał Enrico Gaetano. W sprawach wewnętrznych sejm powinien uchwalić zapłatę wojsku zaległego żołdu, rozwiązać problem kozacki oraz przeprowadzić reformę procedury sejmowej. Również senatorowie w swoich listach wymieniali przyczyny, dla których zwołanie sejmu było konieczne: rozpatrzenie kwestii zwiazanych

${ }_{10}$ W. Witkowski, Stosunki społeczno-kulturalne i językowe na ziemiach ruskich Rzeczypospolitej za panowania Zygmunta III Wazy, [w:] Unia brzeska. Geneza, dzieje $i$ konsekwencje $w$ kulturze narodów słowiańskich, red. R. Łużny, F. Ziejka, A. Kępiński, Kraków 1994, s. 76-82.

${ }_{11}$ T. Chynczewska-Hennel, „Do praw i przywilejów swoich dawnych”. Prawo jako argument $w$ polemice prawosławnych $w$ pierwszej połowie XVII $w$., [w:] Między Wschodem a Zachodem. Rzeczpospolita XVI-XVIII w. Studia ofiarowane Zbigniewowi Wójcikowi $w$ siedemdziesiata rocznice urodzin, red. T. Chynczewska-Hennel et al., Warszawa 1993, s. 53-60.

${ }^{12}$ Zygmunt III do M.K. Radziwiłła, Warszawa 2 XII 1596 r., Biblioteka Książąt Czartoryskich w Krakowie [dalej: B. Czart.] 96, s. 503. 
$z$ liga antyturecka, ustosunkowanie się do sprawozdania komisji krakowskiej etc. ${ }^{13}$ Król w legacji nie podjął kwestii problemów religijnych. Zapewne chciał, by nadchodzace zgromadzenie nie zajmowało się tymi zagadnieniami, gdyż mogły one spowodować konflikty w czasie obrad i rozejście się sejmu bez podjęcia uchwał ${ }^{14}$.

Sejm 1597 r. rozpoczał się 10 lutego w Warszawie ${ }^{15}$. Marszałkiem izby poselskiej został wybrany Piotr Myszkowski (1550-1606), starosta grodowy oświęcimski ${ }^{16}$. Do stolicy początkowo nie dojechali przywódcy obozu różnowierczego: wojewoda kijowski Konstanty Wasyl Ostrogski i jego zięć, Krzysztof Radziwiłł: „pierwszy zakamieniały Syzmatyk, drugi zacięty Kalwin", jak określił ich obrazowo jeden $z$ autorów diariuszy ${ }^{17}$. Symboliczny wspólny wjazd do Warszawy księcia Ostrogskiego i Krzysztofa Radziwiłła był widomym znakiem wspomnianego przymierza $\mathrm{w}$ imię walki $\mathrm{z}$ narzucona przez władyków unią i atakami na zbory protestanckie ${ }^{18}$. Wśród zgromadzonej na sejmie szlachty rozgłaszano pogłoski, jakoby książę miał przybyć na sejm $z$ pięcioma tysiącami prywatnego wojska ${ }^{19}$. Wjazd odbył się 20 lutego 1597 r. w otoczeniu dwóch tysięcy zwolenników Ostrogskiego ${ }^{20}$.

Od 20 do 22 lutego senatorowie wygłaszali swoje wota. W stolicy obecni byli arcybiskupi gnieźnieński Stanisław Karnkowski (1520-1603) i lwowski Jan Dymitr Solikowski (1539-1603), z grona biskupów zaś: krakowski Jerzy Radziwiłł (1556-1600), kujawski Hieronim Rozdrażewski (1546-1600), płocki Wojciech Baranowski

${ }_{13}$ Por. Listy Lwa Sapiehy do Krzysztofa Radziwiłła z 24 IX i 12 X 1596 r., [w:] Archiwum Domu Sapiehów, wyd. A. Prochaska, Lwów 1892, s. 143 i 145.

${ }^{14}$ Instrukcja królewska na sejmiki (brak daty), SRP, t. XX, s. 323-336.

15 Zeitung aus Warschau 1597, Geheimes Staatsarchiv Preußischer Kulturbesitz [dalej: GStAPK], I HA, Rep. 6, nr 11, fasz. 7.

${ }^{16}$ Recesy stanów pruskich $z$ lat 1596-1597, Archiwum Państwowe w Gdańsku [dalej: APG] 300, 29/60, k. 101.

17 Zbiór pamiętników o dawney Polszcze, wyd. J.U. Niemcewicz, t. II, Warszawa 1822 , s. 196.

18 T. Kempa, Konstanty Wasyl Ostrogski (ok. 1524/1525-1608). Wojewoda kijowski i marszałek ziemi wołyńskiej, Torun 1997, s. 149.

19 Recessus oder vielmehr diaria dessen, was publice auf dem allgemeinem reichstag zu Warschau... gehandelt worden im 1597 jahre, SRP, t. XX, Kraków 1907 , s. 436.

${ }^{20}$ Relation vom Reichstage zu Warschau 1597, GStAPK I HA, Rep. 6, nr 11, fasz. 8. Koncepcje religijne Ostrogskiego por. T. Ke m pa, Unijne koncepcje Konstantego Wasyla Ostrogskiego, [w:] Czterechsetlecie zawarcia Unii Brzeskiej 1596-1996. Materiały sesji naukowej zorganizowanej $w$ Toruniu $w$ dniach 28-29 listopada 1996 r., red. S. Alexandrowicz, T. Kempa, Toruń 1998. 
(1548-1615), łucki Bernard Maciejowski (1548-1608), chełmiński Piotr Tylicki (1543-1616) i inflancki Otto Schenking (1554-1637). Wśród wojewodów, którzy przybyli na sejm, obecni byli m.in. poznański Hieronim Gostomski (ok. 1575-1609), wileński Krzysztof Radziwiłł (1547-1603), sieradzki Olbracht Laski (1536-1605), kijowski Konstanty Wasyl Ostrogski (1528-1608), smoleński Jan Abramowicz (w niektórych źródłach również Abrahamowicz, zm. 1602), nowogródzki Teodor Skumin-Tyszkiewicz (1538-1618), mazowiecki Hieronim Parys (1550-1605), rawski Wojciech Wilkanowski (1540-1598), brzeski litewski Krzysztof Zenowicz (1528-1614) oraz chełmiński Mikołaj Działyński (1540-1604). Przyjechali również ministrowie: marszałek wielki koronny Mikołaj Zebrzydowski (1553-1620), kanclerz wielki koronny Jan Zamoyski (1542-1605), kanclerz wielki litewski Lew Sapieha (1557-1633), podkanclerzy koronny Jan Tarnowski (1550-1605), podkanclerzy litewski Gabriel Wojna (zm. 1610) i podskarbi litewski Dymitr Chalecki (1550-1598). W tym gronie przedstawicielami innowierców byli: Krzysztof Radziwiłł (protestant), Jan Abramowicz (protestant), Krzysztof Zenowicz (protestant), Teodor Skumin-Tyszkiewicz (prawosławny). $Z$ diariusza opublikowanego przez Juliana Ursyna Niemcewicza wynika, że protestantów reprezentowali jeszcze: Piotr Niszczycki, Jakub Sienieński, Andrzej Męciński, Mikołaj Talwosz, Iwan Czaplic-Szpanowski, Adam Baliński, Marek Sobieski, Jan Zenowicz, Fabian Czema ${ }^{21}$.

Można było się spodziewać, że tak silna reprezentacja senatorów-innowierców zaowocuje wieloma wystapieniami, w których problematyka wyznaniowa będzie poruszona. Wśród przybyłych senatorów znajdowało się kilka postaci zaangażowanych w sprawy wyznaniowe, zarówno ze strony protestantów, jak i prawosławnych. Byli też katolicy interesujący się tymi kwestiami. Bez wątpienia najważniejszą postacią wśród prawosławnych był wojewoda kijowski, książę Konstanty Wasyl Ostrogski. Istotną rolę polityczną odgrywali też wojewoda wileński oraz kanclerz wielki litewski. Aktywnie w sprawy religijne angażował się Mikołaj Krzysztof Radziwiłł, wojewoda trocki. Obecność dwóch z trzech (Mikołaj Krzysztof Radziwiłł przyjechał do Warszawy już po wotach) przedstawicieli Zygmunta III na synodzie brzeskim: Lwa Sapiehy i Dymitra Chaleckiego

${ }^{21}$ J.U. Niem cewicz, Zbiór pamiętników historycznych o dawnej Polszcze, t. II, Lipsk 1839, s. 140-154. 
wydawać się mogła doskonała okazją do przedstawienia zasad podpisanej przed kilkoma miesiącami w Brześciu Litewskim unii.

Podczas wotów senatorskich najobszerniej swoje stanowisko w sprawach wyznaniowych zaprezentował Konstanty Wasyl Ostrogski podczas swojego wystapienia 22 lutego $^{22}$. W przeciwieństwie do pozostałych senatorów niewiele miejsca poświęcił sprawom ligi antytureckiej czy kwestii nieopłaconego żołdu dla żołnierzy. Po krótkim wstępie przystąpił do obrony prawosławia i praw władyków do zasiadania na swoich biskupstwach. Bronił stanu posiadania cerkwi, ale przede wszystkim argumentował, że: „Ruś przy swej greckiej wierze, która od tak dawnych lat spokoju podług praw od królów panów naszych poprzysiężonych, w pokoju będąc się teraz przez władyki rozerwała, $z$ daleka zaś Jego Królewska Mość żal swój opowiadał, popierając się prawem pospolitym i przywilejami dawnych królów polskich, w czym wielkie ich naruszenie być ukazał, które w prawdzie JKMć w cale onemu zachować i poprzysiądz raczył" ${ }^{3}$.

Wojewoda kijowski wspomniał również, że od 50 lat zasiadał jako senator w „Radzie królów panów swych”, jako prawy szlachcic i człowiek pochodzacy ze starożytnego rodu, zawsze wiernego królom i ojczyźnie. Przypomniał sławne czyny swoich przodków, oddajacych usługi Rzeczypospolitej. Prosił Zygmunta III, by o tym nie zapominał i raczył to docenić. Wskazywał także, że unia, zamiast jednoczyć poddanych władcy, jest przyczyna nowych konfliktów i niepokojów, co też potęguje nieszczęścia w ojczyźnie. Monarcha winien zapobiec dalszym podziałom, powinny odbyć się też wspólne rady dla bezpieczeństwa ojczyzny, po odłożeniu na bok wzajemnych animozji ${ }^{24}$. Ostrogski w swoim wotum skupił się nad zgubnymi skutkami zawarcia tej unii i rozbicia Kościoła prawosławnego. Wpływała ona na rozkład instytucji państwowych, co widoczne było w niskiej efektywności prac sejmu. Ubolewał również nad postępowaniem samego Zygmunta III, którego obarczył wina za rozłam w Kościele prawosławnym ${ }^{25}$.

${ }^{22}$ Chronologia seymu 1597 roku, Biblioteka Kórnicka PAN [dalej: BK PAN] 305, k. 336-338.

${ }^{23}$ Ibidem, k. 336.

${ }^{24}$ Ibidem, k. 338.

25 APG 300, 29/60, k. 120-122. 
Z kolei wojewoda wileński zauważył, że coraz częściej sprawy wyznaniowe znajdowały swoje odzwierciedlenie w instrukcjach sejmikowych i były tam szeroko omawiane ${ }^{26}$. Te liczne niepokoje przenosiły się również na sejmy, na których niestety często je pomijano, ale wracały pod obrady sejmików. To powodowało, że wiele czasu traciło się na przedstawianie tych spraw, co przynosiło coraz to nowe „turbacye”. Radziwiłł zauważył, że trudno jest omawiać kwestie obrony przed zewnętrznym niebezpieczeństwem, kiedy zagrożony jest pokój wewnętrzny ${ }^{27}$.

Inny $z$ wotujących, Jan Abrahamowicz, wojewoda smoleński, zwracał się do króla tymi słowami: „Przeto aby WKMć fidem suam tym, którzy są w religiej różni zachować raczył, aby domowe porządki się stały, aby konfederacyej WKMś czynić dosyć raczył, uniżenie WKMci proszę, bo tą zgoda domowa a dodzierzeniem przymierza przodkowie WKMci państwa i granice koronne rozszerzali. Domowe zgody opatrzywszy całość ojczyzny naszy bezpiecznie zostać może"28.

Przemawiał on nie tylko w charakterze jednego $z$ senatorów, ale przede wszystkim jako protestant, zainteresowany obrona praw i swobód swoich współwyznawców. Jego zdaniem zachowanie pokoju religijnego stanowiło podstawę zgody domowej, pozwalało na utrzymanie państwa w całości. Wypomniał również Zygmuntowi III, że jego poprzednicy właśnie dzięki przestrzeganiu pokoju wewnętrznego oraz zawartemu porozumieniu rozszerzali granice kraju, budując jego potęgę.

Podobnie wypowiadał się wojewoda brzeski Krzysztof Zenowicz, także prosząc króla o wypełnianie postanowień konfederacji warszawskiej, zachowanie praw tych, „którzy sa w religiej różni”. Miało to bowiem ogromne znaczenie dla zachowania pokoju wewnętrznego, ta zgoda domowa i utrzymywanie równowagi wewnętrznej w państwie zaś były podstawą dla przodków Zygmunta III do rozszerzania granic państwa i jego wzmacniania ${ }^{29}$.

Żaden $z$ pozostałych wotujacych senatorów nie podjął w swoim wystapieniu problematyki wyznaniowej, mimo że zabierali głos zarówno arcybiskupi i biskupi (w tym arcybiskup lwowski Jan

\footnotetext{
${ }^{26}$ Ibidem, k. 130-131.

27 Ibidem, k. $131 \mathrm{v}$.

${ }^{28}$ Ibidem, k. 135.

${ }^{29}$ Dyaryusz sejmu..., SRP, t. XX, s. 59.
} 
Dymitr Solikowski, zaangażowany w proces przygotowywania unii brzeskiej i jej wprowadzania), jak i senatorowie świeccy - wojewoda smoleński Jan Abrahamowicz, brzeski litewski Krzysztof Zenowicz i nowogródzki Teodor Skumin-Tyszkiewicz (innowiercy, zaangażowani $\mathrm{w}$ sprawy wyznaniowe). Można przypuszczać, że senatorowie chcieli skupić się na przedstawieniu swojego zdania na tematy poruszone w propozycji królewskiej, bez podnoszenia problemów, które podczas obrad poprzednich sejmów wzbudzały wiele kontrowersji i dyskusji. Bez watpienia poruszenie kwestii wyznaniowych przez większą liczbę senatorów wzmocniłoby głos różnowierców podczas obrad sejmowych. Nie sposób nie połączyć w tym miejscu wystąpień dwóch senatorów: Krzysztofa Radziwiłła i Konstantego Wasyla Ostrogskiego, którzy byli nie tylko przedstawicielami protestantów i prawosławnych, lecz także symbolizowali dosyć nową współpracę między tymi wyznaniami, której pomysłodawcą i głównym realizatorem był przecież wojewoda kijowski. Zapewne ścisłej współpracy między tymi magnatami sprzyjały także ich powiązania rodzinne (wojewoda wileński był zięciem Ostrogskiego).

Bardzo oryginalnym pomysłem, który pojawił się w czasie obrad sejmu 4 marca 1597 r., był postulat objęcia tolerancja religijną wszystkie stany Rzeczypospolitej, a nie tylko szlachtę. Autor tzw. diariusza gdańskiego niestety nie rozwija tej myśli, nie informuje też, kto ją sformułował. Brakuje również wzmianek o późniejszych dyskusjach na ten temat w izbie poselskiej ${ }^{30}$. Jednakże $z$ faktu, że 17 marca w czasie wspólnych obrad szlachty $z$ senatorami postulat ten zostanie ponownie podniesiony przez Krzysztofa Radziwiłła, można wywnioskować, że pomysł narodził się właśnie w otoczeniu wojewody wileńskiego ${ }^{31}$. Idea ta, jak na warunki XVI w., była wręcz unikatowa, choć przede wszystkim liczył się jej praktyczny wymiar. Bardzo nowoczesne podejście pomysłodawcy świadczy także o jego szerokich horyzontach myślowych i dużej wiedzy humanistycznej. Zakładał on bowiem przyznanie swobody wyznania wszystkim mieszkańcom Rzeczypospolitej, niezależnie od przynależności stanowej.

Niezwykle burzliwy przebieg miały wspólne posiedzenia izby senatorskiej i poselskiej. W dniu 7 marca 1597 r. dyskutowały ze sobą dwie grupy: katolicy i „Ruś z heretyki”32. Konflikt dotyczył unii

30 Recessus..., s. 465.

${ }^{31}$ Chronologia sejmu..., s. 498-499.

${ }^{32}$ BK 305, k. 392-395. 
brzeskiej, prawosławni starali się uzyskać zabezpieczenie dla swoich władyków, by nie pozbawiać ich praw. Prosili również o wspólną delegację różnowierców do króla. Głos zabrał w tej sprawie Demian Hulewicz, poseł z Wołynia, protestant, który popierał prośbę prawosławnych ${ }^{33}$, określany przez autora diariusza jako antesignanus (przywódca heretyków). Wypowiedział się negatywnie na temat unii, w której widział narzędzie do „zabijania” tradycyjnej wiary Rusi, oskarżał o to władcę, senat, biskupów unickich i wszystkich obradujących na synodzie w Brześciu. Zarzucił im działanie przeciwko jedności Kościoła greckiego, określając ich działanie jako odrywanie powierzona im trzodę ,jako członki od głowy"34 (tj. od patriarchy konstantynopolitańskiego). Uznał również unię brzeską jako niezgodna $z$ konfederacją warszawska, gdyż została narzucona prawosławnym przez delegatów papieskich i królewskich siła. Podsumowując swoja wypowiedź, Hulewicz zażądał od króla zachowania władyków prawosławnych oraz zniesienia tych, którzy podporządkowali się unii brzeskiej, uzależniając od tego dalsze obrady sejmu ${ }^{35}$. Swoja przemowę powtórzył w obecności senatorów jako przedstawiciel delegacji posłów-dysydentów. Na to wystapienie odpowiedział „Z miejsca swego senatorskiego” Lew Sapieha, kanclerz litewski. Stwierdził, że protestantów nie powinna interesować kwestia rozłamu w Cerkwi prawosławnej, ponieważ nie dotyczyła ich bezpośrednio, ponadto nie byli oni obecni w październiku poprzedniego roku w Brześciu. Opisał również przebieg synodu, na którym był przedstawicielem króla. Wskazał przede wszystkim na to, że licznie zgromadzeni byli tam ludzie wiary greckiej, którzy wcześniej zezwolili swoim władykom na złożenie przysięgi papieżowi i bardzo się tym radowali. Przeciwny temu był jedynie Nicefor, na którego Sapieha skarżył się w senacie, czym wywołał oburzenie i sprzeciw u wojewody kijowskiego, który wdał się w słowną utarczkę $z$ kanclerzem litewskim. W swoim emocjonalnym wystąpieniu zwrócił się nie tylko do przedmówcy, lecz także bezpośred-

${ }^{33}$ Demian Hulewicz był arianinem i klientem wojewody kijowskiego. Przewodniczył synodowi przeciwko unii w październiku 1596 r. Więcej: M. Dowbyszczenko, Na rozdrożu religijnego wyboru. Dramat rodziny Hulewiczów. Hulewiczowie $w$ religijnych ruchach konca XVI - pierwszej połowy XVII wieku, „Rocznik Instytutu Europy Środkowo-Wschodniej”, red. J. Kłoczowski, A. Gil, Lublin 2005, s. $65-87$.

${ }^{34}$ Chronologia comitiorum Regni Poloniae Anno MDXCVII Varsoviae celebratorum, SRP, t. XX, Kraków 1907, s. 153.

${ }^{35}$ BK 305, k. 393. 
nio do króla. Zarzucał Zygmuntowi III łamanie praw i wolności Cerkwi prawosławnej, czego „Jmci panowie ewangelicy w radzie siedzacy fideliter w swoich wociech pomagali”36. Głos zabrał również Piotr Gorajski, kalwinista, poseł $z$ województwa sandomierskiego, występując w obronie ewangelików, którzy mieli takie same prawa „jako i papieżnicy”, a Zygmunt III przysięgał zachowywać je nienaruszone. Zwrócił się też do kanclerza Lwa Sapiehy, któremu miał za złe zniechęcanie monarchy do innowierców. Wspomniał również o wierności dysydentów wobec monarchy i spraw państwowym i przestrzegł, że nie chcieliby oni w przyszłości uciekać się do gwałtu i przemocy ${ }^{37}$.

Po raz pierwszy $\mathrm{w}$ obronie unii staną prawosławny senator, wojewoda nowogródzki T. Skumin-Tyszkiewicz. Skrytykował założenia politycznego i religijnego sojuszu między prawosławnymi a protestantami. Wyrażał zdziwienie, że: „nas panowie ewangelicy i wszyscy heretycy więcej miłują niżby sami siebie, gdyż sami lada jako wierząc, naruszenia naszej starożytnej religii ruskiej pilnie bronia" 38 . Tyszkiewicz wspomniał również o zależności prawosławnych od patriarchatu w Konstantynopolu, zatem pośrednio od sułtana. Niezbyt życzliwie wyrażał się o samych patriarchach, którzy, jego zdaniem, sa marionetkami w rękach sułtana i szukaja protekcji wśród jego urzędników i nałożnic. Te słowa wzburzyły księcia Ostrogskiego i pozostałych dysydentów.

Pojawiły się też głosy popierające unię brzeską, np. w wypowiedzi Jana Zamoyskiego, Lwa Sapiehy czy we wspomnianej przemowie wojewody nowogródzkiego Skumin-Tyszkiewicza. Obaj kanclerze w swoich wystąpieniach stanęli w obronie króla, władyków i zwolenników unii. Negowali prawo protestantów do wypowiadania się w sprawach synodu brzeskiego, który ich nie dotyczył i na którym nie byli obecni ${ }^{39}$. Odrzucili również oskarżenie protestantów, jakoby unia brzeska zawarta została pod przymusem, nie zaś dobrowolnie. Kanclerz litewski wypowiedział się też dość niejasno w kwestii władyków, którzy pozostali przy prawosławiu. Postulował mianowicie, aby nie przekonywać ich siłą do unii, ale wysłać do Rzymu w celu poddania się pod obediencję papieża. Postulat wyjazdu do

${ }^{36}$ In conventu g[e]n[e]rali Warszawien[si] Anno Domini 1597, BK PAN 305, k. 393-394.

${ }^{37}$ Ibidem, k. 394.

38 Chronologia comitiorum..., SRP, t. XX, s. 154.

39 Ibidem. 
Rzymu nie jest oczywisty, ponieważ do unii mogli przystąpić na miejscu. Być może Sapieha zakładał, że moga przekonać ich do tego argumenty samego Ojca Świętego ${ }^{40}$.

Jan Zamoyski zarzucił posłowi wołyńskiemu brak dbałości o sprawy Rzeczypospolitej, a przede wszystkim niekontrolowanie własnego syna, który przystał do Kozaków. Ich bunt, na czele którego stanał Semen Nalewajko, został stłumiony przez Stanisława Żółkiewskiego, hetmana polnego koronnego. Hulewicz odpowiedział, że wcale nie posyłał swojego syna w szeregi buntowników, nie ma na niego wpływu, gdyż ten uciekł w wieku lat 12 ze szkoły, a ponadto już wyjednał sobie przebaczenie u Stanisława Żółkiewskiego. Zamoyski stwierdził, że Zygmunt III powinien ukarać zarówno ojca, jak i syna, gdyż ich obowiązkiem była walka $z$ reszta szlachty po stronie wojsk koronnych, nie zaś w szeregach wrogów ojczyzny. Hulewicz zwrócił mu uwagę, że teraz dyskutuja nad kwestiami wyznaniowymi, natomiast kanclerz próbuje „zatrudniać sprawy sejmowe" innymi problemami, gdyż wcześniej panowało przekonanie w Cerkwi prawosławnej o konieczności podjęcia reform i zbliżenia $z$ Rzymem („na które był przed tym konsens wielu religiej greckiej") ${ }^{41}$. Rozmowa na temat problematyki różnowierczej „jeszcze się aż do wieczora tłukła”" ${ }^{2}$. Dyskusja z 7 marca 1597 r. zakończona została przez Jana Tarnowskiego, który przywoływał szlachtę i senatorów do porządku, wskazując inne ważne problemy kraju, nad którymi miał się pochylić sejm.

$Z$ przytoczonego opisu wyłania się bardzo ostra i nieprzebierająca w środkach polemika sejmowa, w której oponenci sięgali po wszelkie możliwe środki, aby zdyskredytować przeciwnika. Już sam fakt, że kanclerze koronny i litewski wyciagali sprawy rodzinne Hulewicza i jego wyznanie, świadczy o zdeterminowaniu obrońców unii, by przekonać do swoich racji jak najszersze grono posłów i senatorów. Oczywiste jest, że bycie „heretykiem” oraz ojcem młodzieńca działającego na niekorzyść Rzeczypospolitej nie pomogło ani samemu Hulewiczowi, ani tym bardziej unii. Na pewno zręczniej byłoby, gdyby interesów prawosławnych bronił poseł tego wyznania, nie zaś protestant, którego obciążały dodatkowe, młodzieńcze wykroczenia syna ${ }^{43}$.

40 J. Rzońca, op. cit., s. 82.

${ }^{41}$ BK PAN 305, k. 395.

42 Ibidem.

${ }^{43}$ P.N. Żukowicz, Borba protiw unii na sawriemiennych jej litawsko-polskich sjejmach (1585-1600), Petersburg 1897, s. 59. 
Dnia 17 marca została powołana deputacja senatorsko-poselska, której zadaniem było opracowanie projektu konstytucji i znalezienie wyjścia $z$ sejmowego impasu. Obrady tej komisji rozpoczęły się od wotów senatorskich ${ }^{44}$. Chociaż król prosił, by komisja nie zajmowała się sprawą procesu konfederacji, mimo wszystko podnieśli ją w swoich wystapieniach Jan Zamoyski i Bernard Maciejowski ${ }^{45}$. Ten ostatni ograniczył się jedynie do złośliwego komentarza, że innowiercy, domagając się uchwalenia artykułów wykonawczych do konfederacji warszawskiej, nie wiedzą o co prosza, ponieważ nie dzieje im się żadna krzywda ${ }^{46}$. Natomiast kanclerz koronny wystapił jako rzecznik pokoju i tolerancji wyznaniowej: „Życzę, żeby była zgoda i żeby już był exitus, i tak moderować rzeczy, jakoby najlepiej było, bo panowie duchowni powiedaja, że nie moga na to przystapić, gdyż te tej wiary nie przyznawaja. Przeto nie spominając wiary trzeba by co tak generale uczynić, żeby to wszytko komprezendowało" 4 .

Zaledwie po dwóch dniach obrad między deputatami wybuchł konflikt, który spowodował, że rozeszli się oni $\mathrm{w}$ gniewie i bez zakończenia tej sprawy ${ }^{48}$. Dnia 21 marca, po odbyciu tajnej narady $z$ senatorami, król zdecydował się wysłać kilku $z$ nich do posłów $z$ napomnieniem, że powinni się pogodzić i debatować przede wszystkim nad kwestia obrony państwa. Posłowie obiecali przekazać odpowiedzi monarsze. Po długich dyskusjach, które nie przyniosły ani pojednania, ani rozwiązania problemów, zdecydowali się udać wszyscy wraz z marszałkiem do władcy, by oddać dzielące ich sprawy pod jego osąd ${ }^{49}$.

W sprawach wyznaniowych głos zabrał również wojewoda chełmiński Mikołaj Działyński. Skarżył się on posłom i senatorom na bezprawne poczynania biskupa chełmińskiego Piotra Tylickiego. Miał on zajmować kościoły oraz plebanie wraz $z$ ich uposażeniem w majątkach wojewody i nie dopuszczać do budowania nowych świątyń czy szkół protestanckich ${ }^{50}$. W obronie nieobecnego Tylic-

${ }^{44}$ Wśród senatorów-deputatów znaleźli się: K. Radziwiłł, B. Maciejowski, J. Zamoyski.

${ }^{45}$ Wota senatorskie na sejmie $w$ roku [15]97, Archiwum Główne Akt Dawnych w Warszawie [dalej: AGAD], Archiwum Radziwiłłów II [dalej: AR II], nr 367.

${ }^{46}$ Ibidem, k. 1.

47 Ibidem, k. 4.

48 BK PAN 305, k. 420.

49 Ibidem, k. 423.

50 Ibidem, k. 427. 
kiego wypowiedział się biskup łucki Bernard Maciejowski, stwierdzając, że biskup chełmiński nie czyni niczego $z$ prywatnych pobudek, ale jego działania maja umocowanie prawne, ponadto tak nakazuje sprawiedliwość ${ }^{51}$. Wobec tych licznych niesnasek posłowie i senatorowie się rozeszli. Następnego dnia zdecydowano, że marszałek izby zarządzi czytanie próśb poszczególnych województw, spisze je i uda się z nimi do Zygmunta III. Ten zobowiąał się wraz $z$ senatorami następnego dnia dać na nie odpowiedź, co zakończyło obrady w przedostatnim dniu sejmu.

W trakcie obrad sejmu pojawiły się również inne kwestie powiązane ze sprawami wyznaniowymi. Były to: tzw. sprawa Nicefora ${ }^{52}$ oraz problem obsady biskupstwa wileńskiego ${ }^{53}$. Geneza sporu o obsadę tej godności sięgała 1591 r. i dotyczyła wyboru dotychczasowego biskupa wileńskiego Jerzego Radziwiłła na biskupstwo krakowskie. Wywołało to wiele kontrowersji wśród Koroniarzy, szczególnie na sejmikach małopolskich poprzedzających sejm w 1592 r. W tym samym roku nominację na biskupa wileńskiego otrzymał dotychczasowy biskup łucki Bernard Maciejowski. Niewattpliwie te dwie nominacje miały kontekst polityczny. Nominacja Radziwiłła miała odciagnać go od spraw Wielkiego Księstwa Litewskiego i osłabić pozycję jego rodu w tej części Rzeczypospolitej. $Z$ kolei mianowanie Maciejowskiego nowym biskupem wileńskim miało przełamać separatyzm litewski i otworzyć społeczeństwu Korony drogę do godności na Litwie. Zygmuntowi III zależało również na wysłaniu do Wilna człowieka zasłużonego dla Kościoła katolickiego i aktywnie zwalczającego innowierców. Biskup łucki doskonale nadawał się do realizacji tego zadania, gdyż był jednym $z$ inicjatorów zbliżenia Cerkwi prawosławnej w Rzeczypospolitej do Rzymu. Takie motywy uporu króla i dużej niechęci Litwinów sugeruje Marceli Kosman ${ }^{54}$. Czołowym przywódca opozycji wobec nominacji

51 Ibidem.

52 T. Kem pa, Proces Nicefora na sejmie w Warszawie w 1597 roku, [w:] Europa orientalis. Polska ijejwschodni sasiedzi od średniowiecza po współczesność. Studia i materiały ofiarowane Profesorowi Stanisławowi Alexandrowiczowi w 65. rocznice urodzin, red. nauk. Z. Karpus, T. Kempa, D. Michaluk, Toruń 1996, s. 145-168.

53 Por. J. Rzońca, Spór o biskupstwo wileńskie, [w:] Wilno - Wileńszczyzna jako krajobraz i środowisko wielu kultur. Materiały I Międzynarodowej Konferencji, Białystok 21-24 IX 1989 w czterech tomach, t. II, red. E. Feliksiak, Białystok 1992, s. 27.

54 M. Kosman, Reformacja i kontrreformacja w Wielkim Księstwie Litewskim w świetle propagandy wyznaniowej, Wrocław 1973, s. 300. 
Maciejowskiego został wojewoda wileński, Krzysztof Radziwiłł oraz Lew Sapieha, kanclerz wielki litewski. Nie tylko katolicy i protestanci znaleźli się w opozycji, szybko bowiem jej szeregi zasilili również prawosławni. Był to również jeden $z$ elementów współpracy między prawosławnymi a protestantami, sygnowanej przez K. Ostrogskiego i K. Radziwiłła, którą sygnalizowałam.

Śledząc przebieg obrad sejmu 1597 r., można stwierdzić, że w spór o obsadzenie biskupstwa wileńskiego zaangażowani byli przede wszystkim posłowie. Senatorowie starali się nie angażować się jawnie po żadnej ze stron. Przedstawiciele Korony, posłowie i senatorowie, jednomyślnie popierali kandydaturę Polaka na pasterza diecezji wileńskiej, tym samym aprobowali stanowisko i decyzję króla. Kwestia biskupstwa wileńskiego pojawiała się z przerwami podczas dziewięciu dni trwania sejmu (od 27 lutego do 24 marca) i nie została wówczas rozwiąana. Nadal była przedmiotem sporu polsko-litewskiego, jak również wyrazem utrzymującego się separatyzmu litewskiego. Litwini mieli po swojej stronie racje prawne ${ }^{55}$. Trzeci Statut Litewski wyraźnie zastrzegał prawo do urzędów i godności dla Litwinów na obszarze Wielkiego Księstwa Litewskiego ${ }^{56}$. Pozostaje jednak kwestia uporu i niechęć do kompromisu. Litwini mogli przecież wykazać dobra wolę i przyjać nominata Zygmunta III w Wilnie, zwłaszcza że ich rodak zasiadał na biskupstwie krakowskim. Ponadto król zastrzegł, że w przyszłości mieszkańcy Korony nie będa mianowani na to sporne biskupstwo ${ }^{57}$. Senatorowie $z$ Wielkiego Księstwa Litewskiego nie wspierali swoich posłów w sposób wystarczający, gdyż nie chcieli narazić się monarsze. Solidarnie po stronie nominacji królewskiej występowali Koroniarze, aprobując kandydaturę Maciejowskiego. Warto podkreślić, że problem ten absorbował uwagę obradujących aż przez dziewięć dni i mimo to nie został w trakcie sejmu rozwiązany, podsycając ciagle istniejacy separatyzm litewski.

55 S. Ptaszycki, Konfederacja Warszawska roku $1573 w$ trzecim Statucie Litewskim, [w:] Ksiegga pamiatkowa ku uczczeniu czterechsetletniej rocznicy wydania pierwszego Statutu Litewskiego, Wilno 1935, s. 185-213; A. Zakrzewski, Wielkie Księstwo Litewskie (XVI-XVIII w.). Prawo, ustrój, społeczeństwo, Warszawa 2013 , s. $76-77$

56 Statut Wielkiego Xięstwa Litewskigo naprzód, za Naiaśnieyszego Hospodara Króla Jegomości Zygmunta III w Krakowie w Roku 1588... teraz zaś piaty raz, za szczęśliwie panuiącego Naiaśnieyszego Krola jegomości Augusta Trzeciego przedrukowany, Wilno 1744 , rozdz. III, art. 3.

57 BK PAN 305, k. 392-395. 
W tym miejscu można uwypuklić konflikt między Janem Zamoyskim a księciem Konstantym Wasylem Ostrogskim ${ }^{58}$. Ten ostatni słusznie czuł się rozgoryczony i zniechęcony do uczestnictwa w życiu politycznym Rzeczypospolitej, gdyż ataki personalne na jego działalność, jak również kwestia sądu sejmowego nad jego protegowanym Niceforem, były elementami szeroko zakrojonej akcji, która miała zdyskredytować politycznie wojewodę kijowskiego i osłabić jego wpływy na dworze królewskim. Chociaż sejm rozszedł się bez podjęcia uchwał, to niewątpliwie współpraca protestancko-prawosławna wzbudziła w królu i hierarchach katolickich zaniepokojenie. Zgromadzenie z 1597 r. pokazało, że dysydenci potrafia skutecznie stosować obstrukcję podczas obrad sejmowych i blokować podejmowanie jakichkolwiek uchwał w razie niespełnienia ich postulatów. Ów sojusz był widoczny przede wszystkim podczas obrad w izbie poselskiej. Warto podkreślić, że często w sprawach innowierczych zabierali głos wytrawni statyści i doświadczeni parlamentarzyści. Dyskusyjne były jednak niektóre argumenty przez nich wysuwane, jak również kwestia podejmowania się obrony prawosławia i jedności Cerkwi przez protestantów. Natomiast postawa senatorów-innowierców była zdecydowanie kunktatorska i zachowawcza. Poza żarliwymi wotami Konstantego Wasyla Ostrogskiego trudno znaleźć równie przekonujący głos wśród pozostałych senatorów. Walczacy o interesy prawosławia wojewoda kijowski nie był dostatecznie wspierany przez ewangelików, a nawet przez swojego syna Aleksandra.

Bezowocny sejm 1597 r. - jak określił go J. Rzońca - unaocznił duże poruszenie, jakie wywołała unia brzeska w wielonarodowym społeczeństwie Rzeczypospolitej polsko-litewskiej. Obrona prawosławia przez protestantów ukazywała również sojusz między dysydentami. Trudno jednoznacznie wskazać winnych rozejścia się tego sejmu bez podjęcia uchwał. Niewattpliwie wszystkie trzy stany sejmujące wykazały się nieustępliwością i nie potrafiły pójść na kompromis. Wiele spraw omawianych na przełomie lutego i marca 1597 r. w Warszawie znajdzie swoja kontynuację podczas obrad kolejnego sejmu w 1598 r.

${ }^{58} \mathrm{~W}$ kontekście spraw religijnych szerzej pisał o tym m.in. K. Chodynicki, Kościół prawosławny a Rzeczpospolita Polska. Zarys historyczny 1370-1632, Warszawa 1934, s. 368-369. 


\section{Bibliografia}

\section{Ź́ródea ARChiwalne}

Archiwum Główne Akt Dawnych w Warszawie [AGAD]

Archiwum Radziwiłłów dział II „Dokumenty historyczne” 354.

Archiwum Państwowe w Gdańsku [APG]

Recesy stanów pruskich 300, 29/60.

Biblioteka Książąt Czartoryskich [B. Czart.]

96, 97, 2243, 2724 IV.

Biblioteka Kórnicka Polskiej Akademii Nauk w Kórniku [BK PAN]

305.

Geheimes Staatsarchiv Preußischer Kulturbesitz [GStAPK]

I HA, Rep. 6, nr 11, fasz. 7; I HA, Rep. 6, nr 11, fasz. 8.

\section{Ź RÓDEA DRUKOWANE}

Archiwum Domu Sapiehów, wyd. A. Prochaska, Lwów 1892.

Dyaryusze sejmowe r. 1597, wyd. E. Barwiński, Scriptores Rerum Polonicarum, t. XX, Kraków 1911.

Statut Wielkiego Xięstwa Litewskigo naprzód, za Naiaśnieyszego Hospodara Króla Jegomości Zygmunta III w Krakowie w Roku 1588... teraz zaś piaty raz, za szczęśliwie panuiącego Naiaśnieyszego Krola jegomości Augusta Trzeciego przedrukowany, Wilno 1744.

Volumina legum, t. II, wyd. J. Ohryzko, Petersburg 1859.

Zbiór pamiętników historycznych o dawnej Polszcze, wyd. J.U. Niemcewicz, t. II, Lipsk 1839.

\section{OpRacowania}

Dowbyszczenko M., Na rozdrożu religijnego wyboru: dramat rodziny Hulewiczów. Hulewiczowie $w$ religijnych ruchach końca XVI- pierwszej połowy XVII wieku, [w:] „Rocznik Instytutu Europy Środkowo-Wschodniej”, red. J. Kłoczowski, A. Gil, Lublin 2005, s. 65-87.

Chodynicki K., Kościół prawosławny a Rzeczpospolita Polska. Zarys historyczny 1370-1632, Warszawa 1934.

Chynczewska-Hennel T., „Do praw i przywilejów swoich dawnych”. Prawo jako argument $w$ polemice prawosławnych $w$ pierwszej połowie XVII $w$., [w:] Między Wschodem a Zachodem. Rzeczpospolita XVI-XVIII w. Studia ofiarowane Zbigniewowi Wójcikowi $w$ siedemdziesiata rocznice urodzin, red. T. Chynczewska-Hennel, M. Kulecki, H. Litwin, M.P. Makowski, J. Tazbir, Warszawa 1993, s. $53-60$. 
Jarmiński L., Bez użycia siły. Działalność polityczna protestantów w Rzeczypospolitej u schyłku XVI wieku, Warszawa 1992.

Kempa T., Konstanty Wasyl Ostrogski (ok. 1524/1525-1608). Wojewoda kijowski i marszałek ziemi wołyńskiej, Torun 1997.

Kempa T., Proces Nicefora na sejmie $w$ Warszawie $w 1597$ roku, [w:] Europa orientalis. Polska i jej wschodni sąsiedzi od średniowiecza po współczesność. Studia $i$ materiały ofiarowane Profesorowi Stanisławowi Alexandrowiczowi w 65. rocznice urodzin, red. nauk. Z. Karpus, T. Kempa, D. Michaluk, Toruń 1996, s. $145-168$.

Kempa T., Unijne koncepcje Konstantego Wasyla Ostrogskiego, [w:] Czterechsetlecie zawarcia Unii Brzeskiej 1596-1996: materiały sesji naukowej zorganizowanej $w$ Toruniu $w$ dniach 28-29 listopada 1996 r., red. S. Alexandrowicz, T. Kempa, Torun 1998, s. 33-48.

Kempa T., Wobec kontrreformacji. Protestanci i prawosławni $w$ obronie swobód wyznaniowych $w$ Rzeczypospolitej $w$ końcu XVI $i w$ pierwszej połowie XVII wieku, Toruń 2007.

Korolko M., Klejnot swobodnego sumienia. Polemiki wokót konfederacji warszawskiej w latach 1573-1658, Warszawa 1973.

Kosman M., Reformacja i kontrreformacja $w$ Wielkim Księstwie Litewskim w świetle propagandy wyznaniowej, Wrocław 1973.

Kriegseisen W., Stosunki wyznaniowe $w$ relacjach państwo-kościół między reformacja a oświeceniem, Warszawa 2010.

Ptaszycki S., Konfederacja Warszawska roku 1573 w trzecim Statucie Litewskim, [w:] Ksiega pamiatkowa ku uczczeniu czterechsetletniej rocznicy wydania pierwszego Statutu Litewskiego, Wilno 1935, s. 185-213.

Rzońca J., Sejmy z lat 1597 i 1598, cz. 1 (Bezowocny sejm w 1597 roku), Warszawa 1989.

Rzońca J., Spór o biskupstwo wileńskie, [w:] Wilno - Wileńszczyzna jako krajobraz $i$ środowisko wielu kultur. Materiały I Międzynarodowej Konferencji, Białystok 21-24 IX 1989 w czterech tomach, t. II, red. E. Feliksiak, Białystok 1992, s. $23-52$.

Witkowski W., Stosunki społeczno-kulturalne i językowe na ziemiach ruskich Rzeczypospolitej za panowania Zygmunta III Wazy, [w:] Unia brzeska. Geneza, dzieje $i$ konsekwencje $w$ kulturze narodów słowiańskich, red. R. Łużny, F. Ziejka, A. Kępiński, Kraków 1994, s. 76-82.

Zakrzewski A., Wielkie Księstwo Litewskie (XVI-XVIII w.). Prawo, ustrój, społeczeństwo, Warszawa 2013. 
Justyna Gazuszka

\section{The senators and denomination affairs during the Sejm of 1597}

$\mathrm{T}$

he article discusses the attitude of senators to religious matters at the Sejm in 1597. It was an extremely turbulent assembly, the first one after the conclusion of the Brest Union. It shows the great commotion that this act caused in the multinational society of the Polish-Lithuanian Commonwealth. The defence of Orthodoxy by Protestants also showed an alliance between dissidents. In the history of this alliance, the Sejm I am analysing occupies a special place, because for the first time in its forum there was cooperation between Orthodox and Protestants in defense of the Warsaw confederation concluded in 1573. Thanks to the use of Sejm diaries, correspondence and written newspapers, I present Sejm speeches of senators during the sessions of the Sejm. Their juxtaposition makes it possible to state that this issue played a significant role in the internal politics of the Polish-Lithuanian Commonwealth at the end of the $16^{\text {th }}$ century.

Keywords: senators, religious matters, the Sejm, Brest Union, Protestants, Sigismund III Vasa. 